\title{
Effect of Celebrity Endorsement on Purchase Intention and the Intercourse with Customer Satisfaction in Local Brand (Case Study: The use of Ask.fm artist by We Are the Walrus)
}

\author{
Sharfina Adani ${ }^{1}$ \\ ${ }^{1}$ School of Business Management, Bandung Institute of Technology, Indonesia
}

\begin{abstract}
Celebrity endorsement is one of strategies that usually used by companies to promote the brand, which can lead to recognition and awareness from the market. We Are The Walrus as the new local brand in Indonesia also use celebrity endorsement as one of their marketing activities. We Are The Walrus use Ask.fm celebrities to promote their product. Previous research only finds the relationship between the use of celebrity endorsement and purchase intention. Further, in this research researcher aim to identify the relationship between celebrity endorsement to purchase intention and the effect to customer satisfaction. The literature review related to this research is celebrity endorsement, purchase intention, and customer satisfaction. Researcher expect to find that celebrity endorsement have an impact on increasing customer purchase intentions that will lead to customer satisfaction. At the end, this research will also give suggestion for the brand in order to improve their performance for the future promotion activities and to increase customer satisfaction.
\end{abstract}

Keywords: Celebrity Endorsement, Endorser, Purchase Intention, Customer Satisfaction, Local Brand, Indonesia

\section{Introduction}

Indonesia as one of the most densely populated countries in the world becomes a country with considerable market demand by various brands. Not only products from international brands but also products from local brands. To enter the market, a brand must truly understand customer needs and prepare the appropriate marketing strategies. There are so many ways for a brand to introduce new product to the market. One of the most important things to promote a product is by creating creative promotion such as through celebrity endorsement. Celebrity endorsement is considered an effective promotional because it can influences advertising effectiveness, brand recognition, and purchase intentions that finally will lead to customer satisfaction. With today's advertising aggression, within 24 hours most of people forget about the information they got from the advertisements. To prevent that thing, brands use celebrity endorsement to amplify message delivery to customer.

We Are The Walrus is the new local notebook brand of Indonesia that established at $19^{\text {th }}$ May 2014. Notebook from this company has its own uniqueness; it has simple-elegant that reflecting people's identity by put different jobs in the cover, for example engineer, traveler, designer, and filmmaker. Other uniqueness from We Are The Walrus notebooks are the pattern design and some unique facts inside the notebook, which based on the cover design that really represent people's hobby or job. The idea is inspired by nowadays phenomena of people who like to show off about their selves and their true identity in the social media.

We Are The Walrus applied endorsement method to gain public awareness in the first time it launched its product by using Indonesian Ask.fm artist. Ask.fm is a social Q\&A platform that allows the opportunity of asking random questions anonymously or as an identified user. All ask.fm profiles are public and anyone can ask a question. It has no privacy settings - anything posted is publicly viewable. This platform can give great viral marketing impact because if someone like an answer in one account, all his followers will be able to see that answer too although they don't follow the account. Ask.fm artists are ordinary people that have many followers and likes on their answers then become famous in the site. They labeled as "Ask.fm artist" by other users who find their answer interesting. There were significant different of sales occur when the Ask.fm artists promote the notebook in their social media. When endorsers post about the notebook in their social media (Ask.fm, Instagram, or Snapchat), many people like it and ask the official line of We Are The Walrus to purchase the book that make the sales growth much faster than the targets set, even one notebook design can sold only in two 
days. As the new brand they still need to figure out if the endorsement really influence customer purchase intention and if the customer already satisfied with the brand or not. Therefore this research aims to know the effect of celebrity endorsement on purchase intention and customer satisfaction.

\section{Theoretical Background}

\subsection{Celebrity Endorsement}

Celebrity was a person whose name could grab public attention, arouse public interest and generate profit from the public (Gupta, 2009) [1]. A celebrity endorser is "an individual who enjoys public recognition and who uses this recognition on behalf of a consumer good by appearing with it in an advertisement" (McCracken, 1989, page 310)[2]. Celebrities are seen as credible sources of information (Goldsmith et al, 2000) and the credibility of a celebrity is described as the total amount of positive features that create and increase the acceptation of the message (Erdogan, 1999)[3]. Endorsers' credibility considered as an important factor which might affect consumers' purchase intentions and attitudes toward advertising (Lutz, MacKenzie, and Belch, 1983) [1]. There are three dimensions as components of source credibility: 'Trustworthiness', 'Expertise' and 'Attractiveness' (Baker and Churchill, 1977; Giffin, 1967; Hovland, Janis, and Kelley, 1953; Joseph, 1982; Kahle and Homer, 1985; Maddux and Rogers, 1980; Mills and Harvey, 1972)[1].

Trustworthiness refers to the "honesty, integrity and believability of an endorser" (Erdogan, 2001)[4]. Consumer has generally a consideration that celebrities are trustworthy source of communicating information (Goldsmith et al., 2000) [4]. Expertise is defined as "the extent to which a communicator is perceived to be a source of valid assertions" (Hovland et al., 1953) [4]. Attractiveness entails concepts such as intellectual skills, personality properties, way of living, athletic performances and skills of endorsers (Erdogan, 1999) [3].

In today's media cluttered environment where it is difficult to grab consumer's attention, marketing managers are looking for celebrities to gather attention and mileage, giving companies a better chance of communicating their message to consumers (Erdogan, Baker, \& Tagg, 2001; Kamins, Brand, Hoeke, \& Moe, 1989)[5]. In addition to getting consumers to listen to the advertisement, the use of celebrities is also believed to help consumers remember the message of the advertisement and the brand name the celebrity is endorsing (Agrawal \& Kamakura, 1995; Erdogan, 1999; Freidman \& Friedman, 1979; Misra \& Beatty, 1990) [5].

\subsection{Purchase Intention}

Purchase intention was the probability of consumer to buy a product (Burton, Lichtenstein, Netemeyer, and Garretson, 1998) or one's conscious plan to make an effort to purchase a brand in the future (Spears and Singh, 2004)[1]. Purchase intention may amount the chances of a buyer to purchase a producer, larger the buyer intent is, the larger a buyer's intent to purchase a goods (Dodds et al. 1991; Schiffman and Kanuk, 2000)[6]. Buyer intent specifies, buyers will stay up with theirs know-how, first selection and external vicinity to collect information, and make buying choice by assessing substitutes (Zeithaml, 1988; Dodds et al. 1991; Schiffman and Kanuk, 2000; Yang, 2009; Rizwan et al., 2013)[6]. Purchase intention is a very important factor for consumers when they are making decisions about buying any product (Fishbein \& Ajzen, 1975; Ghosh, 1990)[7].

\subsection{Customer Satisfaction}

Customer satisfaction is the result of a customer's perception of the value received in a transaction or relationship - where value equals perceived service quality relative to price and customer acquisition costs (Hallowell, 1996; Heskett et al., 1990; Blanchard and Galloway, 1994)[8]. It is defined as "the individual's perception of the performance of the products or services in relation to his or her expectations" (Schiffman \& Karun 2004, p. 14)[9]. The measurement of customer satisfaction usually includes product quality, value of product, product availability, service scape, personnel issues, and convenience. One of the factor that can help to increase sales is customer satisfaction, because satisfaction leads to customer loyalty (Wilson et al., 2008, p.79)[9]. Improve customer satisfaction can reduce cost related to defective goods and service. Customer satisfaction is a key factor in formation of customer's desires for future purchase (Mittal \& Kamakura, 2001)[10]. 


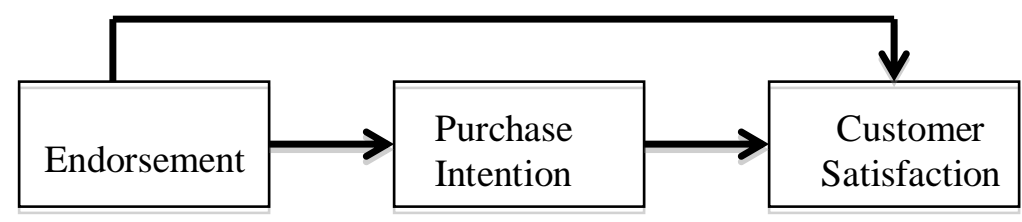

Fig.1: Structural Framework

Figure above show the framework of this research. Three hypothesis has been develop for this study which are given below:

H1: Endorsement has significant influence to purchase intention

$\mathrm{H} 2$ : Endorsement has significant influence to customer satisfaction

H3: Endorsement affecting purchase intention then customer satisfaction

\section{Research Methodology}

This research took place in Indonesia in period of time from March until July 2015. The samples of this research are costumers We Are The Walrus who live in Indonesia, more specifically they are who already buy and contact the official Line ID of We Are The Walrus. In this research, questionnaire that consisted of 36 questions was spread to 150 correspondents. There are three sections in the questionnaire; section 1 indicating demographic information, section 2 indicating glimpse profile of respondents, and section 3 indicating related questions with endorsement, purchase intention, and customer satisfaction. Twenty five of the questions consisted of a range of responses of strongly agree to disagree, on a 5 point scale.

\section{Result}

\subsection{Demographic Data}

TABLE I: Demographic and Glimpse Profile of Respondents

\begin{tabular}{|c|c|c|c|c|}
\hline \multicolumn{3}{|l|}{ Age } & \multicolumn{2}{|c|}{ Ask.fm User } \\
\hline$<15$ & 4 & $3 \%$ & Yes & 114 \\
\hline $15-18$ & 50 & $33 \%$ & No & 36 \\
\hline $19-24$ & 93 & $62 \%$ & \multicolumn{2}{|c|}{ Instagram User } \\
\hline$>24$ & 3 & $2 \%$ & Yes & 145 \\
\hline \multicolumn{3}{|l|}{ Gender } & No & 5 \\
\hline Male & 25 & $17 \%$ & \multicolumn{2}{|c|}{ Source information about brand } \\
\hline Female & 125 & $83 \%$ & Friend & 31 \\
\hline \multicolumn{3}{|l|}{ Job } & Ask.fm & 63 \\
\hline Student & 33 & $22 \%$ & Instagram & 48 \\
\hline Colleger & 103 & $69 \%$ & Other & 7 \\
\hline Employee & 11 & $7 \%$ & \multicolumn{2}{|c|}{ Contact brand's LineID } \\
\hline Entrepreneur & 0 & $0 \%$ & Yes & 137 \\
\hline Other & 3 & $2 \%$ & No & 13 \\
\hline \multicolumn{3}{|l|}{ Domicile } & \multicolumn{2}{|c|}{ Number of books purchased } \\
\hline Jakarta & 54 & $36 \%$ & $1 \mathrm{pc}$ & 107 \\
\hline Bandung & 49 & $32 \%$ & $2-3 \mathrm{pcs}$ & 41 \\
\hline Other & 48 & $32 \%$ & $\geq 4 \mathrm{pcs}$ & 2 \\
\hline \multicolumn{3}{|c|}{ Spending per Month } & & \\
\hline$<\mathrm{Rp} 1,000,000$ & 28 & $19 \%$ & & \\
\hline Rp1,000,000-Rp2,000,000 & 102 & $68 \%$ & & \\
\hline Rp2,000,001-Rp3,000,000 & 15 & $10 \%$ & & \\
\hline$>\operatorname{Rp} 3,000,000$ & 5 & $3 \%$ & & \\
\hline
\end{tabular}

Table above depicts the demographic profile of 150 respondents consist of age, gender, job, and monthly spending also the glimpse profiles about the respondents. Most of respondents are Ask.fm and Instagram users, which those two applications are the main selling channel of the brand. Table also contains customers' source information about the brand, whether they contact the brand or not, and number of book purchased, 


\subsection{Validity and Reliability Test}

TABLE II: Validity and Reliability Table

\begin{tabular}{|l|c|c|c|c|}
\hline \multicolumn{1}{|c|}{ Variables } & Number of items & Cronbach's Alpha & KMO & Sig. \\
\hline Endorsement & 4 & 0.832 & 0.78 & 0 \\
\hline Purchase Intention & 9 & 0.804 & 0.713 & 0 \\
\hline Customer Satisfaction & 12 & 0.87 & 0.864 & 0 \\
\hline
\end{tabular}

From the test result, it is known that value of Cronbach's Alpha are more than 0.6, which means the entire items are reliable. A variable can be said to be reliable if the Cronbach's Alpha value $>0.70$ (Nunnally \& Bernstein, 1994)[11]. Kaiser-Meyer-Oklin value were $>0.6$ which exceeded the recommended value of 0.6 (Kaiser, 1970, 1974)[1]. Barlett's Test of Sphericity (Bartlett, 1954) was $0.000<0.05$ reached statistical significance[1]. So, all variables are reliable and valid.

\subsection{Correlation}

TABLE III: Correlation Table

\begin{tabular}{|c|c|c|c|c|}
\hline & & EN & PI & $\mathrm{CS}$ \\
\hline \multirow{4}{*}{$\mathrm{EN}$} & Pearson Correlation & 1 & $.349^{* * *}$ & $.258^{3 *}$ \\
\hline & Sig. (2-tailed) & & .000 & .001 \\
\hline & $\mathrm{N}$ & 150 & 150 & 150 \\
\hline & Pearson Correlation & $.349^{* *}$ & 1 & $.647^{* *}$ \\
\hline \multirow[t]{3}{*}{ PI } & Sig. (2-tailed) & .000 & & .000 \\
\hline & & 150 & 150 & 150 \\
\hline & Pearson Correlation & $.258^{* *}$ & $.647^{* *}$ & 1 \\
\hline \multirow[t]{2}{*}{$\mathrm{CS}$} & Sig. (2-tailed) & .001 & .000 & \\
\hline & $\mathrm{N}$ & 150 & 150 & 150 \\
\hline
\end{tabular}

From the output above, all Pearson Correlation score have star and all significant score are $<0.05$, which means there are significant correlation between variables.[12]

\subsection{Path Analysis}

The first layer regression for the framework model

TABLE V : Coefficients ${ }^{\text {a }}$

TABLE IV: Model Summary ${ }^{\mathrm{b}}$

\begin{tabular}{|l|r|r|r|r|}
\hline Model & \multicolumn{1}{|c|}{$\mathrm{R}$} & $\mathrm{R}$ Square & $\begin{array}{c}\text { Adjusted R } \\
\text { Square }\end{array}$ & $\begin{array}{c}\text { Std. Error of } \\
\text { the Estimate }\end{array}$ \\
\hline 1 & $.349^{\mathrm{a}}$ & .121 & .116 & .41328 \\
\hline
\end{tabular}

a. Predictors: (Constant), EN

b. Dependent Variable: PI

\begin{tabular}{|c|c|c|c|c|c|}
\hline \multirow[t]{2}{*}{ Model } & \multicolumn{2}{|c|}{$\begin{array}{c}\text { Unstandardized } \\
\text { Coefficients }\end{array}$} & $\begin{array}{c}\text { Standardized } \\
\text { Coefficients }\end{array}$ & \multirow[t]{2}{*}{$\mathrm{t}$} & \multirow[t]{2}{*}{ Sig. } \\
\hline & $\mathrm{B}$ & Std. Error & Beta & & \\
\hline 1 (Constant) & $\begin{array}{r}3.420 \\
191\end{array}$ & .159 & 340 & 21.558 & .000 \\
\hline
\end{tabular}

a. Dependent Variable: PI

EN variable has significant influence to PI variable (Sig.

$0.000<0.005)$, so the structural equation is

$$
\begin{aligned}
& P I=0.349 E N+1
\end{aligned}
$$

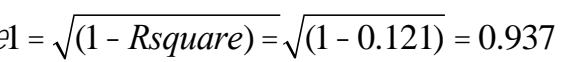

The second layer regression for the framework model 
TABLE VI: Model Summary ${ }^{\mathrm{b}}$

\begin{tabular}{|l|r|r|r|r|}
\hline Model & $\mathrm{R}$ & $\mathrm{R}$ Square & $\begin{array}{c}\text { Adjusted R } \\
\text { Square }\end{array}$ & $\begin{array}{c}\text { Std. Error of } \\
\text { the Estimate }\end{array}$ \\
\hline 1 & $.647^{\mathrm{a}}$ & .419 & .411 & .36937 \\
\hline
\end{tabular}

a. Predictors: (Constant), PI, EN

b. Dependent Variable: CS
TABLE VII: Coefficients ${ }^{\mathrm{a}}$

\begin{tabular}{|c|c|c|c|c|c|}
\hline \multirow[t]{2}{*}{ Model } & \multicolumn{2}{|c|}{$\begin{array}{c}\text { Unstandardized } \\
\text { Coefficients }\end{array}$} & $\begin{array}{c}\text { Standardized } \\
\text { Coefficients }\end{array}$ & \multirow[t]{2}{*}{$\mathrm{t}$} & \multirow[t]{2}{*}{ Sig. } \\
\hline & B & Std. Error & Beta & & \\
\hline (Constant) & 1.176 & .289 & & 4.077 & .000 \\
\hline $1 \mathrm{EN}$ & .022 & .040 & .037 & .559 & .577 \\
\hline PI & .694 & .073 & .633 & 9.446 & .000 \\
\hline
\end{tabular}

a. Dependent Variable: CS

EN variable has no significant influence to CS variable (Sig. 0.577>0.005) then EN variable is eliminated from the model. While PI variable has significant influence to CS variable (Sig. $0.000<0,005$ ), so the structural equation is

$$
\begin{gathered}
C S=0.633 P I+2 \\
2=\sqrt{(1 \quad \text { Rsquare })}=\sqrt{\left(\begin{array}{ll}
1 & 0.419)
\end{array}=0.762\right.}
\end{gathered}
$$

\section{Conclusion}

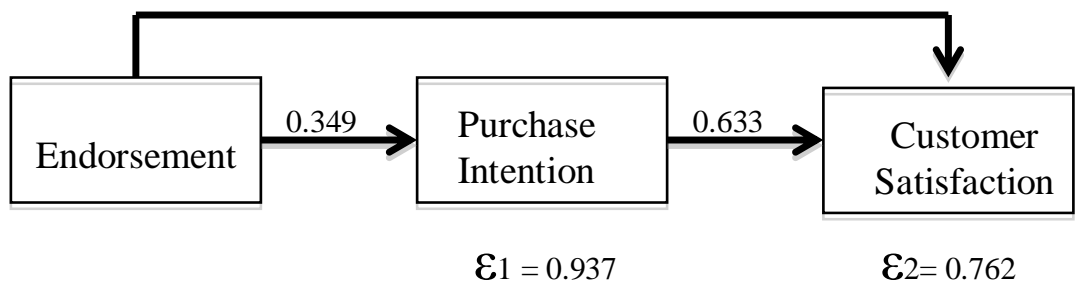

Fig. 2: Structural Framework after Path-analysis

After doing the data analysis, proved that endorsement (EN) has direct influence to purchase intention (PI) as big as $34.9 \%$ (H1 is accepted) and does not have significant influence to customer satisfaction (CS) (therefore $\mathrm{H} 2$ is rejected). Endorsement has indirect influence to customer satisfaction through purchase intention as big as $0.349 \mathrm{x} 0.633=0.22$ (H3 is accepted). Purchase Intention (PI) has direct influence to customer satisfaction as big as $63.3 \%$. So, customer satisfaction is significantly affected by purchase intention.

\section{Acknowledgement}

Researcher would like to give deepest appreciation for the help and support to these following people who have contributed in making this research possible.

Mr.Harimukti Wandebori, as my supervisor, for giving me his guide, advice, suggestions, comments, and sharing his knowledge, and giving his help to finish this research.

Ms.Fitri Aprilianty, as my tutor, for giving her time and helping me check this research.

Mrs. Shimaditya Nuraeni, as my Statistical Lecturer, for giving me suggestion for data processing.

Mr. Dalzi Danil, as the brand owner, for giving me his time and helping me by sharing about his brand.

My family, for their moral and financial support, also encouragement and spirit so this research can be finished.

\section{Reference}

[1] Au-Yeung Pui Yi, "Effects of Celebrity Endorsement on Consumer Purchasing Intention of Apparel Products," Bachelor of Arts thesis, Institute of Textile \& Clothing The Hongkong Polytechnic University, Hongkong, China, 2012.

[2] L. Langmeyer and M.Walker, "A First Step to Identify the Meaning in Celebrity Endrosers," Advances in Consumer Research, vol.18, 00.364-371, 1991. 
[3] M.L.L Hoekman, "Celebrity Endorsement How Does Celebrity Endorsement Influence The Attitude Towards The Brand And How Does Negative Publicity Affect This Relationship?” Bachelor Thesis, Tilburg University, Netherland, 2015.

[4] S.R ul Hassan and R.A Jamil, "Influence of Celebrity Endrosement on Consumer Purchase Intention for Existing Product: A Comparative Study,"Departement of Management Science, University of Haripur, Pakistan, 2014.

[5] Abhishek and Arvind Sahay, "Role of Culture in Celebrity Endorsement: Brand Endorsement by Celebrities in Indian Context," Indian Institute of Management, India, 2013.

[6] M. Rizwan et al., "The Impact on Branded Product on Consumer Purchase Intentions," Journal of Public Administration and Govarnance, vol.4, no.3, 2014.

http://dx.doi.org/10.5296/jpag.v4i3.5849

[7] M.Bilal and T. Ali, "Factor Inflencing Consumers Purchase Intentions towards Private Brands,' JISR-MSSE, vol.11, no.2, 2013.

[8] A.A Jahanshahi et al,. "Study the Effectof Customer Service and Product Quality on Customer Satisfaction and Loyalty," International Journal of Humanities and Social Science, vol.1, no.7, 2011.

[9] J.M. Agbor, "The Relationship between Customer Satisfaction and Service Quality: a study of three Service sectors in Umea," Masters Thesis, Umea School of Business, Sweden, 2011.

[10] R. Mosahab, O. Mohamad, and T. Ramayah, "Service Quality, Customer Satisfaction, and Loyalty: A Test of Mediation," International Business Research, vol.3, no.4, October 2010.

[11] H. Momtaz et al., "Customers Satisfaction on Online Shopping in Malaysia," International Journal of Business and Management, vol.6, no.10, October 2011.

http://dx.doi.org/10.5539/ijbm.v6n10p162

[12] Metode Penilitian Administrasi, Alfabeta, Prof. Dr. Sugiyono, Bandung, 2007. 